\title{
Climate paradox of the G-8: legal obligations, policy declarations and implementation gap
}

O paradoxo climático do G-8: obrigações legais, declarações
de políticas e lacuna de implementação

HANS GUENTER BRAUCH*

Rev. Bras. Polít. Int. 55 (special edition): 30-52 [2012]

This article analyzes the climate policy performance of the G-8 from 1992 to 2012 based on their legal commitments (Annex-1 and Annex-B countries) under the UNFCCC (1992) and the Kyoto Protocol (1997) and their policy declarations on their GHG reduction goals until 2050. A "climate paradox" has emerged due to a growing implementation gap in Canada, USA and Japan, while Russia, Germany, UK, France and Italy fulfilled their GHG reduction obligation.

\section{Introduction: from the Earth Summit in Rio (1992) to Rio+20 (2012)}

The outcome of the United Nations Conference on Environment and Development (UNCED) in Rio de Janeiro in June 1992 and of the second Earth Summit (Rio+20) in June 2012 point to a fundamental change in global climate governance. While in 1992 two international conventions - United Nations Framework Convention on Climate Change (UNFCCC) and the United Nations Convention on Biological Diversity (UNCBD) - were signed and several policy documents were approved (Agenda 21, Rio Declaration on Environment and Development, Statement of Forest Principles), two decades later the UN Conference on Sustainable Development (UNCSD) adopted a "legally nonbinding outcome document": The Future We Want, calling for a green economy in the context of sustainable development (SD) and poverty reduction, an institutional arrangement for SD, a framework for action and follow-up. ${ }^{1}$

While the first Earth Summit in Rio established a framework for international climate governance with legally-binding commitments for developed industrialized countries (Annex-1, UNFCCC) and the Kyoto Protocol (1967) adopted quantitative emissions limitations and reduction obligations (QELROs) for Annex

\footnotetext{
* Chairman of the Peace Research and European Security Studies (AFES-PRESS). Retired Professor at the Free University of Berlin, Germany (hg.brauch@onlinehome.de).

1 See: UNGA (2012). Draft resolution: The Future We Want, A/66/L.56 (July 24, 2012).
} 
B countries, two decades later global climate governance was paralyzed due to a failure of its Conference of Parties (COP) in Copenhagen (2009), Cancún (2010) and Durban (2011) to adopt a legally-binding post-Kyoto climate regime once the obligations adopted under the KP expire by the end of 2012.

As Annex-1 and Annex-B countries, the Group of 8 (G-8) shares a major responsibility for this policy failure, together with other G-20 countries, which contribute more than $80 \%$ of global GHG emissions. Three G-8 countries face a climate paradox due to their inability to implement their legal obligations and policy declarations for GHG reduction targets for 2050.

What are the legal obligations of the G-8 under the UNFCCC and KP? Which political commitments did their heads of state and governments declare for reducing their GHG emissions until 2050? How did their GHG emissions change from 1990 to 2010? Why did the climate leaders of 1992 become climate laggards in 2012? Why did the four European G-8 members (Germany, UK, France and Italy) and most if EU-27 succeed both regards? The second thesis is that sticking to a business-as-usual approach may result in high economic costs and major international and human security consequences during the $21^{\text {st }}$ century (EU 2008; UN 2009; Brauch 2009; Scheffran, Brzoska, Brauch et al. 2012). The chapter concludes calling for alternative national and regional strategies of sustainability transition in the energy, transport, production and consumption sectors resulting in a low-carbon economy and reducing potential resource conflicts by shifting to renewable energy.

\section{Legal obligations of the G-8 under UNFCCC (1992) and KP (1997)}

The UNFCCC distinguishes industrialized countries (Annex 1) with general obligations and other nations defining its goals (Art. 2) as: "stabilization of greenhouse gas concentrations in the atmosphere at a level that would prevent dangerous anthropogenic interference with the climate system" and that this "should be achieved within a timeframe sufficient to allow ecosystems to adapt naturally to climate change, to ensure that food production is not threatened and to enable economic development to proceed in a sustainable manner." In Art. 3 paragraph 1 , the parties agreed that they would "protect the climate system for the benefit of present and future generations of humankind, on the basis of equity and in accordance with their common but differentiated responsibilities and respective capabilities". Under Art. 4, the Annex-1 countries "shall adopt national policies [and] [...] measures on the mitigation of climate change, by limiting its anthropogenic emissions of greenhouse gases and protecting and enhancing its greenhouse gas sinks and reservoirs," and take "the lead in modifying longer-term trends in anthropogenic emissions," recognizing "that the return by the end of the present decade to earlier levels of anthropogenic emissions of carbon dioxide and other greenhouse gases [...] would contribute to such modification.” They would 
also aim to return "individually or jointly to their 1990 levels these anthropogenic emissions of carbon dioxide and other greenhouse gases," and they "shall provide new and additional financial resources to meet the agreed full costs incurred by developing country Parties in complying with their obligations under Article 12, paragraph 1" and "they shall also provide such financial resources, including for the transfer of technology, needed by the developing country Parties to meet the agreed full incremental costs of implementing measures."

Based on the Berlin Mandate (1995), the Kyoto Protocol (KP 1997) contains specific QELROs to implement these policies and measures, including:

(i) Enhancement of energy efficiency in relevant sectors of the national economy.

(ii) Protection and enhancement of sinks and reservoirs of greenhouse gases not controlled by the Montreal Protocol[...]; promotion of sustainable forest management practices, afforestation and reforestation.

(iii) Promotion of sustainable forms of agriculture in light of climate change considerations.

(iv) Research on, and promotion, development and increased use of, new and renewable forms of energy, of carbon dioxide sequestration technologies and of advanced and innovative environmentally-sound technologies.

(v) Progressive reduction or phasing out of market imperfections, fiscal incentives, tax and duty exemptions and subsidies in all greenhousegas-emitting sectors $[\ldots]$.

(vi) Encouragement of appropriate reforms [...] aimed at promoting policies and measures which limit or reduce emissions of greenhouse gases not controlled by the Montreal Protocol.

(vii) Measures to limit and/or reduce emissions of greenhouse gases [...] in the transport sector.

(viii) Limitation and/or reduction of methane emissions through recovery and use in waste management, as well as in the production, transport and distribution of energy.

According to Art. 3 of the KP, the states agreed that

the Parties included in Annex I shall, individually or jointly, ensure that their aggregate anthropogenic carbon dioxide equivalent emissions of the greenhouse gases listed in Annex A do not exceed their assigned amounts, calculated pursuant to their quantified emission limitation and reduction commitments inscribed in Annex B and in accordance with the provisions of this Article, with a view to reducing their overall emissions of such gases by at least 5 per cent below 1990 levels in the commitment period 2008 to 2012.

All G-8 states actively participated in the negotiation of the KP and accepted their national $\mathrm{CO}_{2}$ reduction targets. The USA is the only country that failed to ratify the KP, while Canada withdrew after COP-17 in Durban in December 
2011. Thus, as of January 2012 the US and Canada are not (or not any more) legally-bound by their obligations under the KP.

\section{G-8 policy declarations of their long-term commitments (2007-2012)}

The concept of a Climate Paradox refers to a fundamental contradiction in the behavior of developed (G-8) and threshold countries (G-20), as reflected in their policy declarations and their lacking implementation. The G-8 confirmed the IPCC findings and supported the goal to stabilize the increase of global average temperature at $2{ }^{\circ} \mathrm{C}$ above the pre-industrial level by 2100 . From 2007 to 2011 , the G-8, in their annual summit declarations, i.e. in May 2011 in Deauville (France), declared as the goal:

of developed countries reducing emissions of greenhouse gases in aggregate by $80 \%$ or more by 2050 , compared to 1990 or more recent years. Consistent with this ambitious long-term objective, we will undertake robust aggregate and individual mid-term reductions. [...] Similarly, major emerging economies need to undertake quantifiable actions to reduce emissions significantly below business-as-usual by a specified year.

But in May 2012 at the G-8 conference in Camp David (USA), this commitment was dropped and replaced by a statement on Energy and Climate Change:

10. [...] We also recognize the importance of pursuing and promoting sustainable energy and low carbon policies in order to tackle the global challenge of climate change. [...]

12. We recognize that increasing energy efficiency and reliance on renewables and other clean energy technologies can contribute significantly to energy security and savings, while also addressing climate change and promoting sustainable economic growth and innovation. [...]

13. We agree to continue our efforts to address climate change and recognize the need for increased mitigation ambition in the period to 2020, with a view to doing our part to limit effectively the increase in global temperature below $2{ }^{\circ} \mathrm{C}$ above pre-industrial levels, consistent with science. [...]

As the Durban (COP-17, 2011) statement and the Rio+20 outcome document, this policy declaration lacks any legally-binding commitments.

\section{Changes in GHG emissions of the G-8}

The world regions have contributed differently to global warming. According to Botzen et al. (2008) and Höhne et al. (2010), ${ }^{2}$ from 1800 to 1988, the top-five

2 Botzen, W.J.W. et al. (2008): "Cumulative $\mathrm{CO}_{2}$ emissions: shifting international responsibilities for climate debt”, in: Climate Policy, 8: 570; Höhne, N. et al. (September 24, 2010): “Contributions of individual countries' emissions to climate change and their uncertainty", in: Climatic Change (Springer). 
historic industrial $\mathrm{CO}_{2}$ emitters were: OECD North America 33.2\% (29.7\%), OECD Europe 26.1\% (16.6\%), former USSR 14.1\% (12.5\%), China 5.5\% (6.0\%), and Eastern Europe 5.5\% (4.8\%). Developed countries contributed 83.8\% of historic industrial $\mathrm{CO}_{2}$ emissions and $67.8 \%$ of total $\mathrm{CO}_{2}$ emissions, while developing countries accounted for industrial $\mathrm{CO}_{2}$ emissions of $16.2 \%$ and $32.2 \%$ of total $\mathrm{CO}_{2}$ emissions including carbon emissions from deforestation (Banuri et al. $1996,94) .^{3}$ The ratio in per capita emissions between both groups was more than 10 to 1 . According to Höhne $(2010,179-180)$, from 1890-2007, for cumulative energy-related $\mathrm{CO}_{2}$ emissions non-OECD countries accounted for $42 \%$, the USA for $28 \%$, the EU for $23 \%$, Russia for $11 \%$, China for $9 \%$, other OECD countries for $5 \%$, Japan for $4 \%$, India for $3 \%$, and the rest of the world for $18 \%{ }^{4}$

According to the International Energy Agency (IEA 2011, 9) in 2009, the annual top-ten GHG emitting countries were responsible for two-thirds of the global annual energy-related $\mathrm{CO}_{2}$ emissions. Based on this review of long-term and recent global GHG emission trends, the performance of the G-8 with regard to their legal and declaratory obligations are assessed based on data of Eurostat (2011), IEA (2011) and UNFCCC (2011) for Annex B countries (Table 1).

Table 1. Commitments of the State-parties under UNFCCC and KP.

\begin{tabular}{|c|c|c|c|c|c|c|c|c|c|c|}
\hline Country & \multicolumn{2}{|c|}{$\begin{array}{l}\text { UNFCCC } \\
\text { (1992) }\end{array}$} & \multicolumn{2}{|c|}{$\begin{array}{l}\text { Kyoto Protocol } \\
\text { (1997) }\end{array}$} & \multirow{2}{*}{$\begin{array}{l}\text { Reduction } \\
\text { goal } \\
(\%)\end{array}$} & \multirow{2}{*}{$\begin{array}{c}\text { EU-15 } \\
\text { Reduction } \\
\text { goal } \\
(\%) \\
\text { Burden- } \\
\text { sharing } \\
\text { agreement } \\
(1998)\end{array}$} & \multicolumn{4}{|c|}{$\begin{array}{c}\text { Performance }(1990-2009) \\
\text { GHG reductions in \% } \\
1990 \text { (base year) }\end{array}$} \\
\hline \multirow[t]{2}{*}{$\begin{array}{c}\text { G-8 } \\
\text { countries }\end{array}$} & $\begin{array}{c}\text { Annex } \\
1\end{array}$ & $\begin{array}{c}\text { Annex } \\
2\end{array}$ & $\begin{array}{c}\text { Annex } \\
\text { B }\end{array}$ & $\begin{array}{c}\text { In } \\
\text { transition }\end{array}$ & & & $\begin{array}{c}\text { EU } \\
\text { Eurostat } \\
2011\end{array}$ & $\begin{array}{l}\text { IEA } \\
2011\end{array}$ & $\begin{array}{r}\text { UNF } \\
(2009 \\
\text { use c } \\
\text { and f } \\
\text { (LUI }\end{array}$ & $\begin{array}{l}\text { CCC } \\
\text { Land- } \\
\text { ange } \\
\text { restry } \\
\text { JCF) }\end{array}$ \\
\hline & & & & & & & & & Excl. & Incl. \\
\hline 1) USA & $\mathrm{X}$ & & $\mathrm{X}$ & & -7 & & & +6.7 & +7.2 & +5.6 \\
\hline 2) Canada & $\mathrm{X}$ & & $\mathrm{X}$ & & -6 & & & +20.4 & +17.0 & +29.8 \\
\hline 3) Japan & $\mathrm{X}$ & & $\mathrm{X}$ & & -6 & & & +2.7 & -4.5 & -5.0 \\
\hline 4) Germany & $\mathrm{X}$ & & $\mathrm{X}$ & & -8 & -21 & -25.4 & -21.1 & -26.3 & -23.0 \\
\hline 5) UK & $\mathrm{X}$ & & X & & -8 & -12.5 & -27.1 & -15.2 & -26.9 & -27.7 \\
\hline 6) France & $\mathrm{X}$ & & $\mathrm{X}$ & & -8 & 0 & -8.3 & +0.6 & -7.7 & -12.9 \\
\hline 7) Italy & $\mathrm{X}$ & & X & & -8 & -6.5 & -5.0 & -2.0 & -5.4 & -13.3 \\
\hline 8) Russia & & $\mathrm{X}$ & & $\mathrm{X}$ & 0 & & & -29.7 & -36.9 & -57.2 \\
\hline
\end{tabular}

Source: elaborated by the author.

3 Banuri, T., 1996: "Equity and social considerations", in: IPCC (1995).

4 Höhne, N. et al., September 24, 2010: "Contributions of individual countries' emissions to climate change and their uncertainty", in: Climatic Change. 


\section{Implementing legal obligations and policy declarations: European Union (Germany, UK, France and Italy)}

In 2012, 25 (except Malta and Cyprus) of the EU-27 countries are Annex B countries and all are parties to the UNFCCC and of the KP. 15 EU members were covered by its burden-sharing agreement (1998) adopting different targets. Most of the $25 \mathrm{EU}$ Annex B countries submitted five national communications to the UNFCCC (Table 2). GHG emissions for most of EU-27 countries declined from 1990 to 2009. With the EU enlargements of 2004 (EU15+10) and 2007 (Bulgaria, Romania), ten transition countries joined whose emissions had dropped with the collapse of their socialist system in 1989.

The GHG emissions of the EU-27 were 4,614.5 million tons of $\mathrm{CO}_{2}$ equivalents in 2009 and they had declined by $17.4 \%$ or by 974 million tons since 1990. But in 2009 the drop by $7.1 \%$ or by 354.5 million tons was largely due to the world economic crisis. According to a Eurostat report, by 2009 the biggest increases occurred in Spain $(+26.8 \%)$, Portugal $(+24 \%)$, Greece $(+14.5 \%)$ and Ireland $(+14.5 \%)$ accounting for $13.6 \%$ of the EU total. Spain $(+11.8 \%)$ and Ireland $(+1.5 \%)$ were also above the targets of the EU's burden-sharing agreement. As these countries are severely affected by the financial crises, with their declining economic growth their emissions will also drop.

Among the EU-27, the four largest countries (Germany, UK, France, and Italy) were responsible for $54.9 \%$ of the GHG weighted emissions in $\mathrm{CO}_{2}$ equivalents. Of these - according to IEA's statistics - by 2009 Germany had reduced its emissions by $-21.1 \%$, Sweden by -20.9 , the UK by $-15.2 \%$, Denmark by $-7.2 \%$, and Belgium by $-7 \%$ since 1990 . Compared with EU-15's burden-sharing targets, Sweden had reduced its emissions by $-20.9 \%$, the UK by $-14.6 \%$, France by $-8.3 \%$, Finland by $-6.6 \%$, and Germany by $-4.5 \%$.

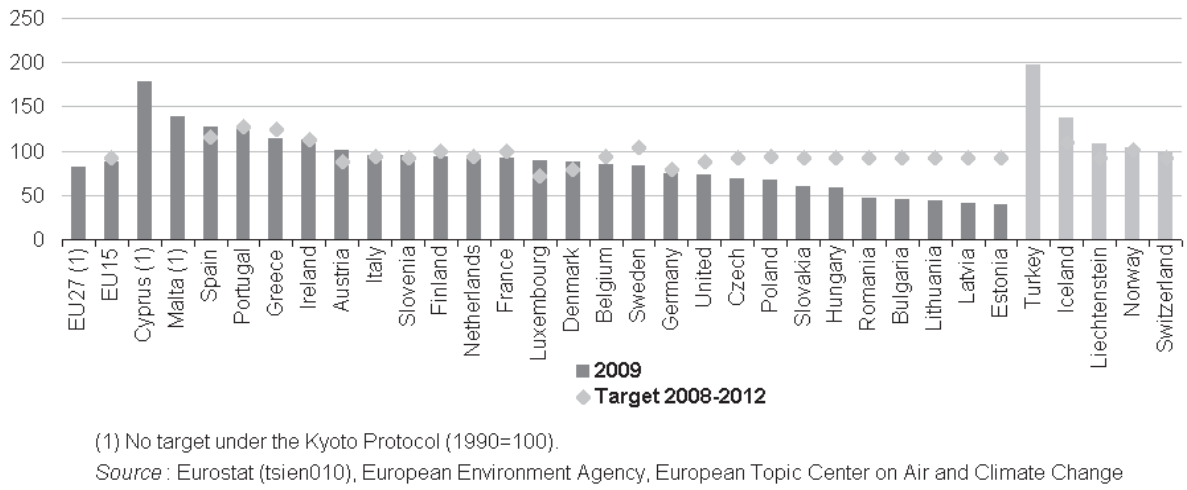

Figure 1. Greenhouse gas emissions and targets per country (Index Kyoto base year $=100)$.

Source: Eurostat: Climate change statistics (June 2011), at <http://epp.eurostat.ec.europa.eu/portal/page/portal/ product_details/dataset?p_product_code=TSIEN010>, accessed April 18, 2012. 
However, within the EU there were also several laggards that missed both their reduction targets under Annex B of the KP and under the EU-15's burdensharing approach, led by Spain $(+37.7 /+11.8 \%)$, Portugal $(+35.3 /-3.0 \%)$, Ireland $(+32.4 /-0.8 \%)$, and Greece (28.6/-10.5\%), whose combined share of the EU-27 was only $13.7 \%$ in 2009 .

Thus, globally the EU-27 has clearly been the leader in implementing their commitments under the KP. The EU also adopted in 2008 a decision to aim by 2020 at a $20 / 20 / 20$ target:

- A reduction in EU greenhouse gas emissions of at least 20\% below 1990 levels.

- $20 \%$ of EU energy consumption to come from renewable resources.

- A 20\% reduction in primary energy use compared with projected levels, to be achieved by improving energy efficiency. ${ }^{5}$

The EU offered to increase its emissions reduction to $30 \%$ if other major emitting countries would commit to significant reductions under a global climate agreement. On May 26, 2010, the European Commission published a communication called Analysis of options to move beyond $20 \%$ greenhouse gas emission reductions and assessing the risk of carbon leakage, which revisits the analysis of the implications of different levels of ambitions (20\% and 30\% targets) and assesses the risk of carbon leakage. ${ }^{6}$

Table 2's data were gathered as follows:

- The first five columns are based on the data of the UNFCCC website on the national communications of Annex-1 countries, at <http://unfccc.int/ national_reports/annex_i_natcom_/items/1095.php> and Non-Annex-1 countries, at <http://unfccc.int/national_reports/non-annex_i_natcom/ items/2716.php>; accessed on April 18.

- Column 6 on the reduction goals (QELROs) according to Annex B of the Kyoto-Protocol are taken from the legal text, at: <http://unfccc.int/ resource/docs/convkp/kpeng.html>; accessed on April 18, 2012.

- Column 7 with the EU's burden-sharing agreement of 1998 of the EU-12 on national GHG reduction targets can be found in: Desai,

5 European Commission, 2008: Communication from the Commission to the European Parliament, The Council, The European Economic and Social Committee and the Committee of the Regions 2020 by 2020, COM (2008) 30 final (Brussels, January 23); at: <http://eur-lex.europa.eu/LexUriServ/LexUriServ.do?uri=CO M:2008:0030:FIN:EN:PDF>; see also at: <http://ec.europa.eu/clima/policies/package/index_en.htm>.

6 See: European Commission, 2010: Communication from the Commission to the European Parliament, The Council, The European Economic and Social Committee and the Committee of the Regions. Com(2010) 265 final (Brussels, 26.5.2010); Analysis of options to move beyond 20\% greenhouse gas emission reductions and assessing the risk of carbon leakage [SEC(2010) 650] at: <http://eur-lex.europa.eu/LexUriServ/LexUriServ.do? uri=COM:2010:0265:FIN:EN:PDF>. 
Surajee; Michaelowa, A. 2001: "Burden sharing and cohesion countries in European climate policy: a case study from Portugal, in: Climate Policy, 1, 3: 327-341.

- Column 8 with the Eurostat data that shows the implementation of the EU-12's targets of its burden-sharing agreement until end of 2009 was calculated by the authors based on a table in: Eurostat: "Climate change statistics; from Statistics Explained; Data from June 2011"; at: <http://epp. eurostat.ec.europa.eu/statistics_explained/index.php/Climate_change_ statistics>; accessed on April 18, 2012.

- Column 9: IEA, 2011: "CO2 emissions: Sectoral Approach", in: IEA: IEA Statistics, 2011 Edition: CO2 Emissions From Fuel combustion Highlights (Paris. OECD/IEA): 46-50, at <http://www.iea.org/co2high lights/co2highlights.pdf>; accessed on April 18, 2012.

- Columns 10 and 12: "1990 CO2" and "2008 CO2", in: IEA: IEA Statistics, 2011 Edition: $\mathrm{CO}_{2}$ Emissions From Fuel combustion Highlights (Paris. OECD/IEA): 46-50, at <http://www.iea.org/co2highlights/co2highlights. pdf $>$; accessed on April 18, 2012.

- Columns 11 and 13: "1998 GHG" and "2009 GHG", in: Eurostat: "Climate change statistics; from Statistics Explained; Data from June 2011", at <http://epp.eurostat.ec.europa.eu/statistics_explained/index. php/Climate_change_statistics>; accessed on April 18, 2012.

- Column 14: "2010 CO2", in: "List of countries by carbon dioxide emissions”, at <http://en.wikipedia.org/wiki/List_of_countries_by_ carbon_dioxide_emissions $>$; accessed on April 18, 2012.

- Column 15: "EU Share", in: Eurostat: "Climate change statistics; from Statistics Explained; Data from June 2011", at <http://epp.eurostat. ec.europa.eu/statistics_explained/index.php/Climate_change_statistics>; accessed on April 18, 2012; source of document: Eurostat (env_air_ind and env_air_gge), European Environment Agency, European Topic Center of Air and climate Change.

- Columns 16 and 17: CO2 Emissions per Cap., "2008” and "Annual change from 1970 to 2008", in: UNDP, 2011: Human Development Report 2011: Sustainability and Equity: A Better Future for All (New York: UNDP): 146-149, at <http://hdr.undp.org/en/media/HDR_2011_ EN_Complete.pdf>; accessed April 18, 2012.

- Column 18: Global total \% of CO2 (2008), in: "List of countries by carbon dioxide emissions"; at: <http://en.wikipedia.org/wiki/List_of_countries_ by_carbon_dioxide_emissions>; accessed April 18, 2012. 


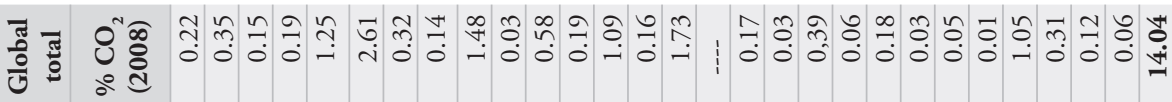

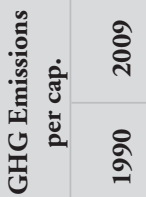

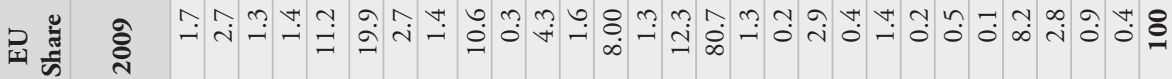

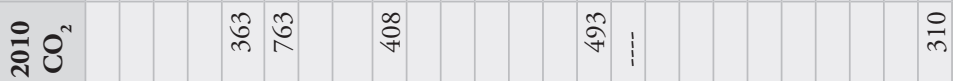

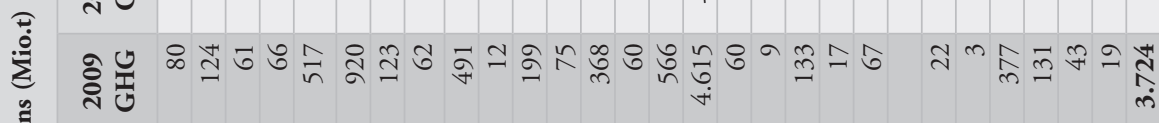

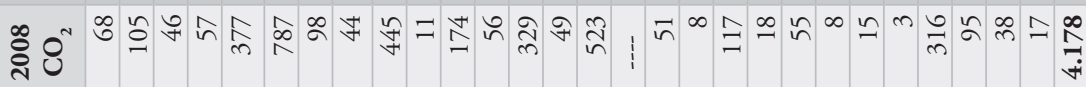

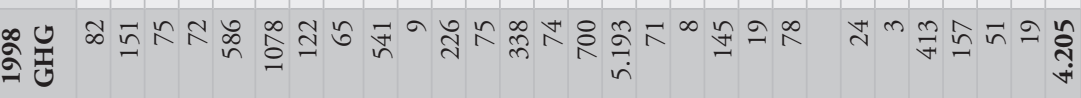



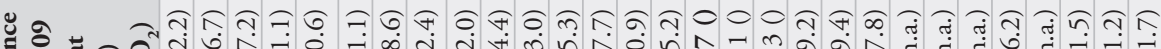

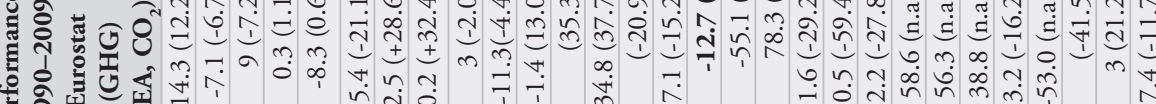

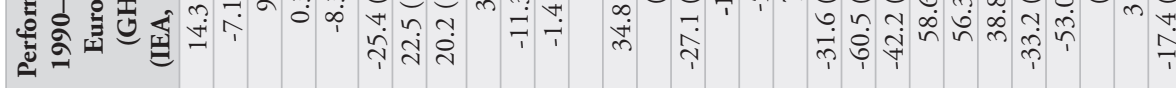

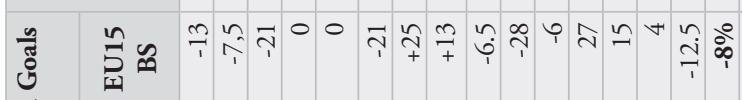

点

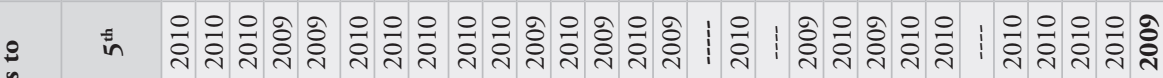

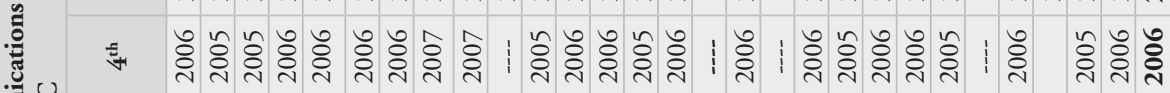

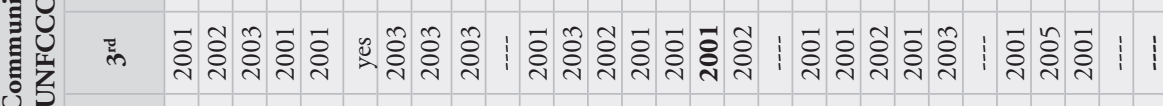




\section{From leaders to laggards: Canada, USA and Japan}

The US had tabled climate change on the G-7 agenda in June 1988 and was a leader until the US Congress failed to ratify the KP. Japan, which hosted COP-3 (UNFCCC) in Kyoto, where the KP was adopted in December 1997, was on the way to meet its GHG reduction goals by 2012 before the triple catastrophe on March 11, 2011.

\section{United States' climate policy}

In 2008 , the USA had contributed about $18.11 \%$ to the global total of $\mathrm{CO}_{2}$ emissions and took the $2^{\text {nd }}$ rank between China and the European Union (E-27). Its per capita emissions amounted to 17.3 tons of $\mathrm{CO}_{2}$ and the average annual \% growth from 1970 to 2008 was $-0.6 \%$. According to IEA's statistics from 1990 to 2009 , the total $\mathrm{CO}_{2}$ emissions of the USA increased by $6.7 \%$ and were thus $13.7 \%$ above its targets under Annex B of the KP. In its Fifth National Communication (NC) to the UNFCCC (CAR 2010), the Obama Administration summarized major climate change-related developments in the US between 1990 and 2007:

- Total US emissions rose by 17\% from 1990 through 2007. The US GDP increased by $65 \%$ and population increased by $21 \% . \mathrm{CO}_{2}$ accounted for approximately 85\% of total US GHG emissions in 2007 (CAR 2010, 5).

- $\mathrm{CO}_{2}$ from fossil fuel combustion has accounted for approximately $79 \%$ of global warming potential-weighted emissions since 1990. Emissions of $\mathrm{CO}_{2}$ from fossil fuel combustion increased at an average annual rate of $1.3 \%$ from 1990 through 2007. The [...] factors influencing this trend include general domestic economic growth, and significant growth in emissions from transport activities and electricity generation. [...] $\mathrm{CO}_{2}$ emissions from fossil fuel combustion increased by $21.8 \%$.

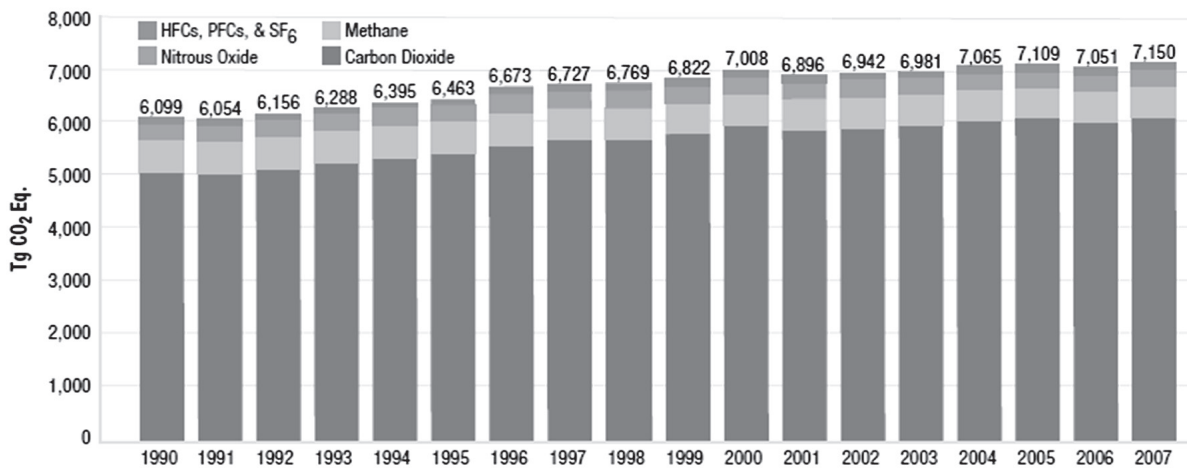

Figure 2. Growth in US greenhouse gas emissions by gas.

Source: US (CAR 2010, 25). 
On the policies and measures, the $5^{\text {th }}$ US NC (CAR 2010) noted by using the year 2005 as the base year instead of the year 1990 agreed to in the UNFCCC and in the KP:

- In June 2009, the US House of Representatives passed the landmark American Clean Energy and Security Act, which includes economy-wide GHG reduction goals of 3\% below 2005 levels in 2012, 17\% below 2005 levels in 2020, and 83\% below 2005 levels in 2050 [p. 6]. [...] With additional mitigation measures, [...] the United States would have a GHG reduction goal of $17 \%$ by 2020 (CAR 2010, 6). [...]

- Renewable energy [...] currently accounting for 3\% of US electric generation excluding conventional hydro, or $9 \%$ including conventional hydro (CAR 2010, 13).

- Petroleum remains the largest single source of US primary energy consumption; in 2008 it accounted for $37.7 \%$ of total US energy demand, down from $41 \%$ in 2005 . Natural gas accounts for $24.4 \%$, coal for $22.4 \%$, nuclear for $8.1 \%$, conventional hydro for $2 \%$, and other renewables for $3 \%$.

These data clearly show that both the goal of a stabilization of GHG under the UNFCCC and the 7\% reduction goal under the KP have not been met.

Table 3. Recent trends in US GHG emissions and sinks.

\begin{tabular}{|l|r|r|r|r|r|r|}
\hline \multicolumn{1}{|c|}{ Gas/Source } & $\mathbf{1 9 9 0}$ & $\mathbf{1 9 9 5}$ & \multicolumn{1}{c|}{$\mathbf{2 0 0 0}$} & \multicolumn{1}{c|}{$\mathbf{2 0 0 5}$} & \multicolumn{1}{c|}{$\mathbf{2 0 0 6}$} & \multicolumn{1}{c|}{$\mathbf{2 0 0 7}$} \\
\hline Carbon dioxide $\left(\mathrm{CO}_{2}\right)$ & $5,076.7$ & $5,407.9$ & $5,955.2$ & $6,090.8$ & $6,014.9$ & $6,103.4$ \\
\hline Fossil fuel combustion & $4,708.9$ & $5,013.9$ & $5,561.5$ & $5,723.5$ & $5,635.4$ & $5,735.8$ \\
\hline Electricity generation & $1,809.7$ & $1,938.9$ & $2,283.2$ & $2,381.0$ & $2,327.3$ & $2,397.2$ \\
\hline Transportation & $1,484.5$ & $1,598.7$ & $1,800.3$ & $1,881.5$ & $1,880.9$ & $1,887.4$ \\
\hline Industrial & 834.2 & 862.6 & 844.6 & 828.0 & 844.5 & 845.4 \\
Residential & 337.7 & 354.4 & 370.4 & 358.0 & 321.9 & 340.6 \\
Commercial & 214.5 & 224.4 & 226.9 & 221.8 & 206.0 & 214.4 \\
US territories & 28.3 & 35.0 & 36.2 & 53.2 & 54.8 & 50.8 \\
\hline Total & $\mathbf{6 , 0 9 8 . 7}$ & $\mathbf{6 , 4 6 3 . 3}$ & $\mathbf{7 , 0 0 8 . 2}$ & $\mathbf{7 , 1 0 8 . 6}$ & $\mathbf{7 , 0 5 1 . 1}$ & $\mathbf{7 , 1 5 0 . 1}$ \\
\hline Net emissions & $\mathbf{5 , 2 5 7 . 3}$ & $\mathbf{5 , 6 1 2 . 3}$ & $\mathbf{6 , 2 9 0 . 7}$ & $\mathbf{5 , 9 8 5 . 9}$ & $\mathbf{6 , 0 0 0 . 6}$ & $\mathbf{6 , 0 8 7 . 5}$ \\
\hline sources and sinks) & & & & & & \\
\hline
\end{tabular}

Source: US CAR (2010, 26-27).

While the US failed to meet its commitments since 1990, given the political blockade in the US Congress it is unclear how the Obama Administration may achieve its $17 \%$ reduction goal by 2020 based on the year 2005, which represents a $5 \%$ reduction based on 1990 as the base year. It becomes difficult to foresee how the US will achieve its $80 \%$ reduction goal by 2050 . Thus, during the US G-8 Presidency in May 2012 in Camp David this goal was dropped. 


\section{Canada's climate policy}

In 2008, Canada had contributed about $1.8 \%$ to the global total and took the $7^{\text {th }}$ rank between Germany and Iran. Canada's per capita emissions in 2008 amounted to 16.4 tons of $\mathrm{CO}_{2}$ and the average annual percentage growth from 1970 to 2008 amounted to $+0.1 \%$. According to IEA's statistics from 1990 to 2009, Canada's $\mathrm{CO}_{2}$ emissions increased by $20.4 \%$ and were thus $27.4 \%$ above its targets under Annex B of the KP. In its $5^{\text {th }} \mathrm{NC}$ to the UNFCCC of February 12, 2010, the Canadian government described its performance as follows:

- Canada's 2007 GHG emissions from all sources, excluding LULUCF, were $747 \mathrm{Mt}$ of $\mathrm{CO}_{2}$-eq., a 26\% increase from 1990 levels of $592 \mathrm{Mt}$.

- The Canadian economy grew by almost 60\% from 1990 to 2007 . However, the GHG intensity of Canada's economy has progressively decreased, particularly since 1996. As a result, in 2007, the GHG intensity of Canada's economy was $21 \%$ lower than in 1990 . Canada's national population also grew by $18 \%$, largely through immigration.

- In its $5^{\text {th }} \mathrm{NC}$ the government admitted that in 2007 Canada's GHG emissions were 33.8\% above its Kyoto target (Figure 3). Between 1990 and 2007, Canada's GHG emissions increased faster than its population; only the GHG per capita and per energy use and the GHG intensity declined. Emissions increased in all sectors, except for land-use change and forestry.

- On December 11, 2011, Canada announced its unilateral withdrawal from the KP. Canada would join a new global commitment with China and the US. Canada's Prime Minister Harper claimed that the KP hurt the competitiveness of its economy. The huge performance and implementation gap and the increasing pressure of the energy industry to exploit Canada's huge potential of oil sands persuaded Canada's conservative Harper government as the first country to opt out of the $\mathrm{KP}$ (1997) to give preference to domestic economic interests over global commitments. 


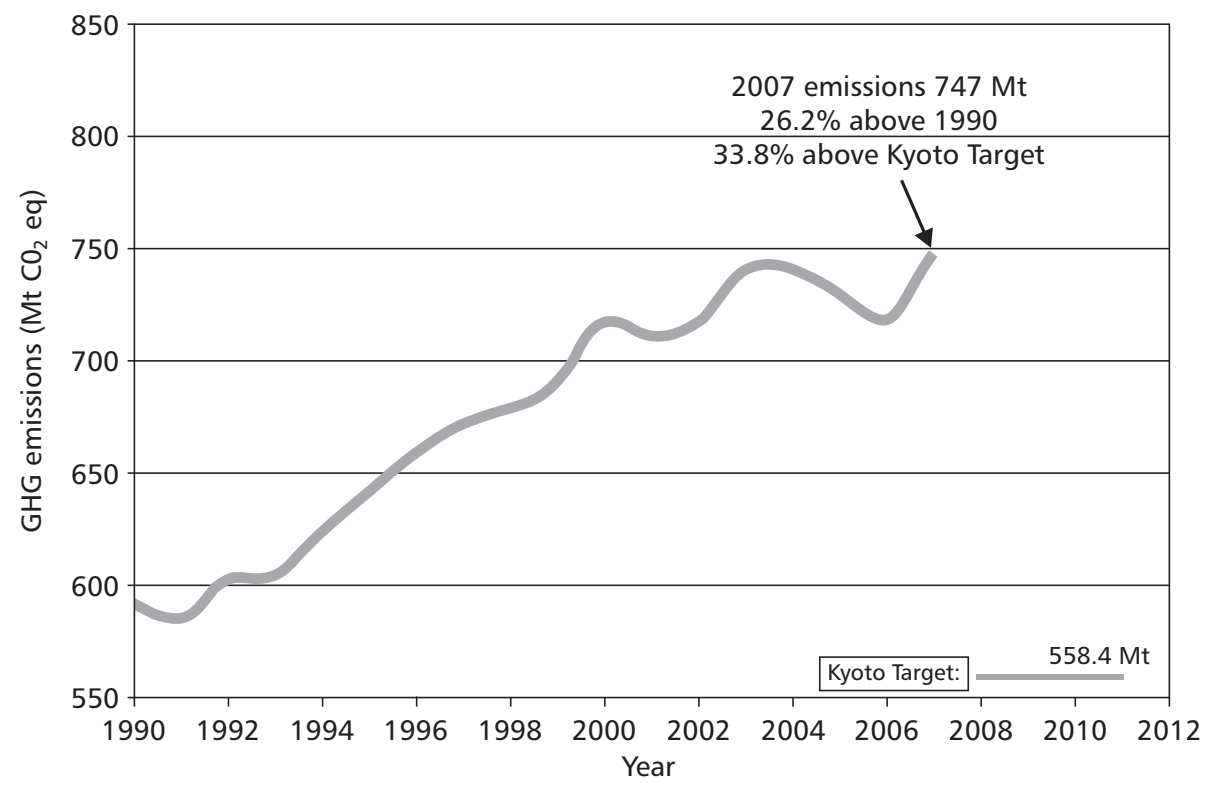

Figure 3. Canadian GHG emissions trends and targets.

Source: $5^{\text {th }}$ NC (Canada 2010, 21).

\section{Japan's climate policy}

In 2008, Japan had contributed about $1 \%$ to the global total and took the $6^{\text {th }}$ rank between India and Germany. Japan's per capita emissions in 2008 amounted to 9.5 tons of $\mathrm{CO}_{2}$ and the average annual growth from 1970 to 2008 amounted to $+0.7 \%$. According to IEA's statistics (1990-2009), Japan's $\mathrm{CO}_{2}$ emissions were $8.7 \%$ above its targets under the KP. Due to its dependence on fossil energy imports, since the 1960s Japan held a technological lead in energy-efficient technologies.

Hiroshi Ohta $(2011,1381)$ argued that "a lack of strong and stable political leadership on climate change [...] has also allowed well-organized economic interests and the economy ministry to solidify an industry-oriented policy coalition." $\mathrm{He}$ noted that Prime Minister Yukio Hatoyama began "to move back into its natural position as a vital force in international climate change negotiations," when he pledged at the UN Summit on Climate Change on September 22, 2009, "that Japan would reduce GHG emissions by $25 \%$ by 2020 from the 1990 level if all major emitters also commit to ambitious reduction targets. [...] He proposed [...] an international scheme for the provision of additional technological and financial support for developing countries while assuring developing countries' 'measurable, reportable, and verifiable' emission reduction targets." When he was forced out in 2010, Prime Minister Naota Kan announced in December 2010 plans for cap-and-trade, a carbon tax and a feed-in tariff for renewables. 
With the Fukushima nuclear catastrophe in March 2011 the vulnerability of Japan's energy policy relying heavily on nuclear energy became obvious. With the shutting down of most nuclear reactors "there will be a significant reliance on carbon-polluting forms of power generation over the short and medium term, which will make the $25 \%$ goal [...] extremely difficult to achieve". ${ }^{7}$ Kazuhiko Takeuchi and Nicholas Turner claimed that prior to this 'triple disaster' Japan was on track to meet the KP's target of $-6 \%$ by 2012 :

largely due to the recent sharp economic downturn, efforts by companies and households to reduce $\mathrm{CO}_{2}$ emissions and improve efficiency were also playing a significant role. In the longer term, it was seen as difficult to achieve further emissions reductions through energy efficiency, and plans to invest in renewable energy were limited. Rather, Japan's policies to achieve its more ambitious long-term emissions reduction targets ( $25 \%$ by 2020 , and $80 \%$ by 2050) depended heavily upon expanded use of nuclear power. [...] But in the aftermath of the Fukushima Daiichi nuclear crisis, these plans have been abandoned, leading many observers to express severe doubts that Japan will meet its long-term emissions targets.

Despite long-term energy strategies of MITI of the early 1990s to make Japan the leader in renewables (Krupp 1997), little was implemented and by 2011 they only supplied 6\% of its energy. After the Fukushima disaster, Prime Minister Kan stated that "renewables will become a major pillar of the country's energy policy, along with energy savings," especially wind, solar, geothermal and biomass. Takeuchi and Turner saw a unique opportunity to enhance "sustainability through reconstruction [...] for Japan to build more sustainable, low-carbon communities." They conclude that "the government's renewed commitment to developing renewable energy suggest that the country need not abandon its target of an $80 \%$ reduction in emissions by 2050 . As the reconstruction of the affected areas begins, the hope is that it will lead the way for Japan's long-term shift towards a low-carbon economy - and ultimately a more sustainable society." 8 Luta concluded in late 2011 that

without a Basic Law on Global Warming and a plan coordinating domestic policy instruments, just how Japan means to achieve its abatement goals remains unclear. So far, all the climate policy instruments pushed by the Democratic Party of Japan, relying on economic stimuli that would ultimately raise energy costs, have been rendered ineffective by opposition from powerful stake-holders. Energy policy remains therefore the only channel through which Japan's GHG emissions could be cut.

7 Alexandru Luta: "Climate Policy after the Crisis: A New Japan", in: The Diplomat, 29 April 2011, at $<$ http://thediplomat.com/a-new-japan/2011/04/29/climate-policy-after-the-crisis/>.

8 Kazuhiko Takeuchi; Nicholas Turner, UNU-ISP, 2011: "Japan's triple disaster and climate change policy", in: EastAsia Forum, 23 May 2011; at: <http://www.eastasiaforum.org/2011/05/23/japan-s-triple-disaster-andclimate-change-policy/>. 
Whether Japan will be able to meet its GHG reduction goals by 2020 and 2050 depends on fundamental decisions on its future energy policy and on an efficient political strategy for a transition towards a sustainable development path in the first half of the $21^{\text {st }}$ century.

\section{Achievements due to economic transition: special case of Russia}

In 2009, Russia was the fourth largest $\mathrm{CO}_{2}$ emitter behind China, the USA and India, and for all GHG emissions, including deforestation, Russia held the fifth place behind China, the US, Brazil and Indonesia. In the cumulative emissions for 1850 to 2007 , with $8 \%$ Russia was the third largest emitter. According to UNFCCC's (2009) assessment with land-use change Russia reduced its GHG emissions since 1990 by $-57.2 \%$, without land-use change and forestry by $-36.9 \%$ and according to IEA's (2011) analysis by $-29.7 \%$ (Table 1). Russia's major decline in GHG emissions since 1990 coincided with the dissolution of the Soviet Union and the transition of Russia from a socialist to a market economy. Prior to COP-15 (2009) in Copenhagen, Russia considered reducing its GHG by 25\% until 2020. ${ }^{9}$

\section{Climate paradox and the performance and implementation gap}

As a transition country, Russia had the highest decline in GHG emissions of the G-8 without any reduction obligations. While most European democracies have nearly fully implemented their legal commitments under the KP (or the EU's burden-sharing agreement) and have taken up the leadership, while others that tabled climate change on the international agenda (e.g. US President Reagan in June 1988) became laggards (USA, Canada, Japan).

As a result of prevailing business-as-usual policies on the impacts of anthropogenic global climate change, humankind is confronted with a Climate Paradox. A fundamental paradigm shift with a "transformation of global cultural, environmental, economic [...] and political [...] relations" (Oswald Spring and Brauch 2001, p. 1487) is needed for coping with global environmental change (GEC) by aiming at a "sustainability revolution and sustainable peace." Both visions refer to different coping strategies with GEC:

- In the first vision of business-as-usual cornucopian perspectives prevail that suggest primarily technical fixes [...], defense of economic, strategic and national interests with adaptation strategies that are in the interest of and affordable for the "top billion" of OECD countries in a new geopolitical framework.

9 Elena Lioubimtseva: "Russia's Role in the Post-2012 Climate Change Policy: Key Contradictions and Uncertainties”; at: <http://forumonpublicpolicy.com/spring2010.vol2010/spring2010archive/Lioubimtseva. pdf> (17 August 2012). 
- In the alternative vision of a comprehensive transformation a sustainable perspective has to be developed and implemented into effective new strategies and policies with different goals and means based on global equity and social justice.

Both opposite scientific visions imply different policy consequences:

- The vision of business-as-usual with minimal reactive adaptation and mitigation strategies will most likely increase the probability of a "dangerous climate change" [...] or catastrophic GEC with both linear and chaotic changes in the climate system and their sociopolitical consequences that represent a high-risk approach.

- To avoid these consequences the alternative vision and sustainability perspective requires a change in culture $[\ldots]$, worldviews $[\ldots]$, mindsets $[\ldots]$ and new forms of national and global governance (Oswald Spring and Brauch 2001, 1487-1488).

The UN Secretary-General in his report on climate change and security (UN 2009) distinguished two discourses linking climate change, security and sustainable developments that referred to five channels through which climate change (as a threat maximizer) could affect security, or as "threat minimizers" could result in sustainable development (Figure 4).

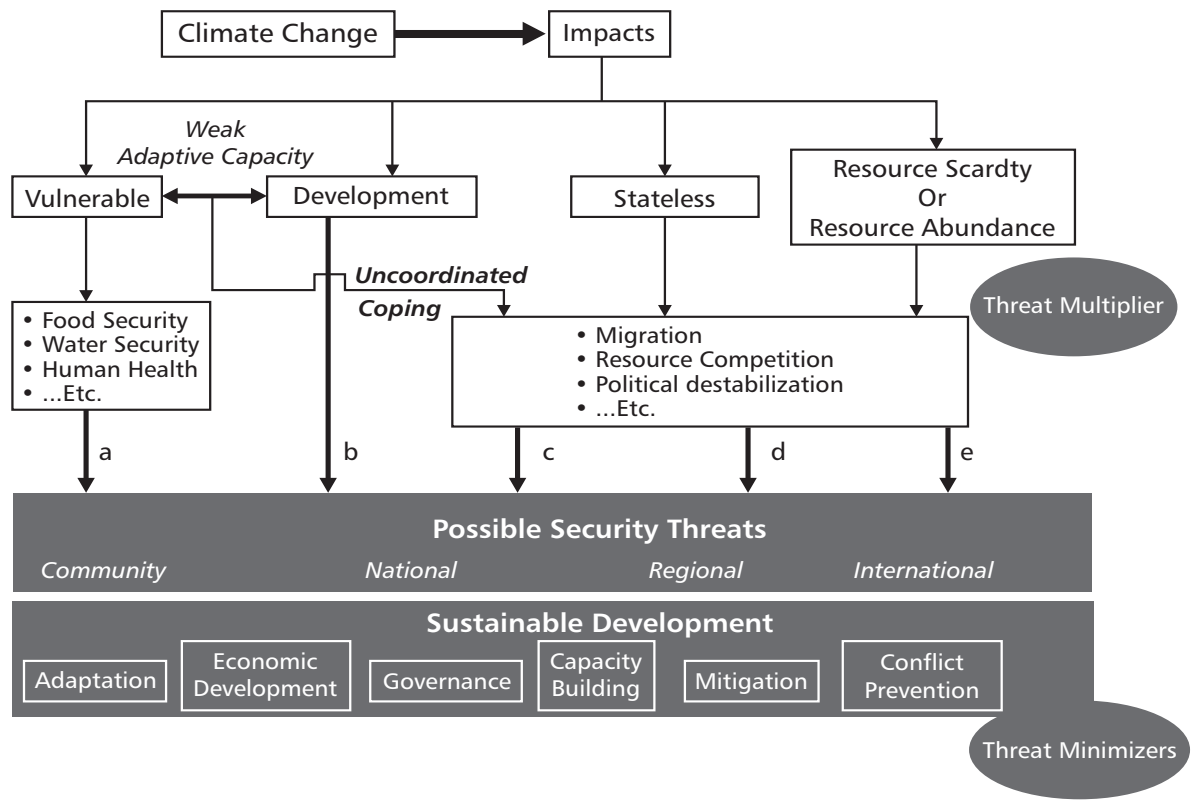

Figure 4: Channels of threat multipliers and threat minimizers.

Source: UN-SG (2009, 7). 
Many OECD states - among them three G-8 countries - failed to implement their legal obligations and to adopt a post-Kyoto regime. The Durban outcome "included a decision by Parties to adopt a universal legal agreement on climate change as soon as possible, and no later than 2015." This refers to a business-asusual mentality among government representatives to postpone legally-binding commitments to their successors.

Democratic governance did not determine the different climate performance of the G-8. Rather, there is a significant implementation gap among democracies between a majority of EU countries (leaders) and large OECD countries in North America and in the Asia-Pacific (laggards). Among the G-8 countries different strategies of "business first" and reformist approaches towards a "long-term transformative change to sustainability" could be observed.

\section{EU Energy Roadmap 2050: transition to a low-carbon economy}

On December 15, 2011 the European Commission (2011) released its Energy Roadmap 2050, according to which

[t] he $\mathrm{EU}$ is committed to reducing greenhouse gas emissions to $80-95 \%$ below 1990 levels by 2050 in the context of necessary reductions by developed countries as a group. [...] In this Energy Roadmap 2050 the Commission explores the challenges posed by delivering the EU's decarbonization objective while at the same time ensuring security of energy supply and competitiveness. It responds to a request from the European Council. ${ }^{10}$

Figure 5 illustrates the share of the individual energy sources for the year 2005 and their projected share for 2030 and 2050 for the $27 \mathrm{EU}$ member countries by end of 2011. The share of renewables is projected to increase to $20 \%$ by 2020 , $25 \%$ by 2030 and $40 \%$ to $60 \%$ by 2050 . The EU's Energy Roadmap 2050 relied on several "current trend" scenarios.

10 See: Communication from the Commission to the European Parliament, the Council, the European Economic and Social Committee and the Committee of the Regions, COM(2011) 885/2. 


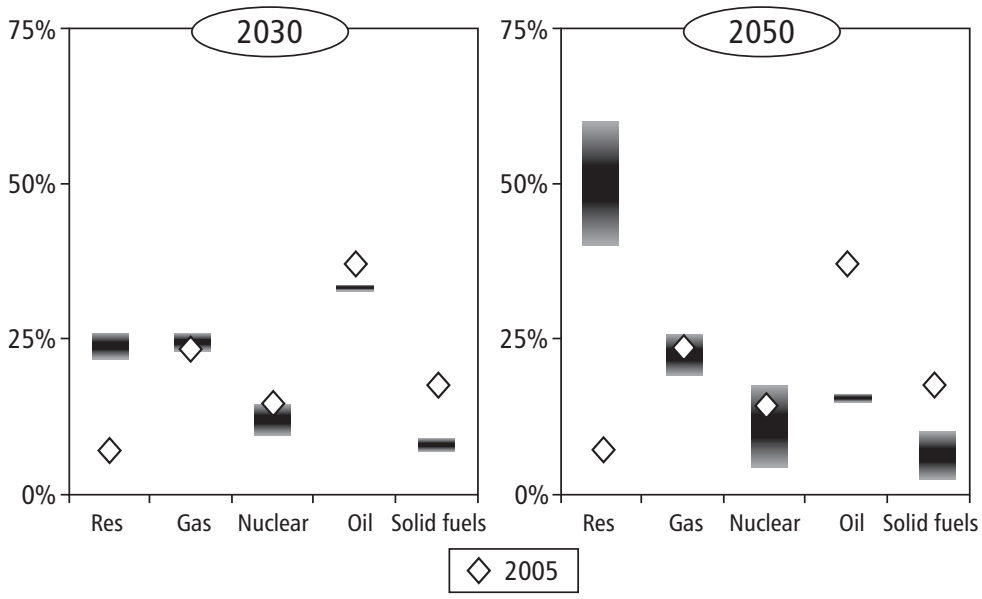

Figure 5. EU decarbonization scenarios - 2030 and 2050 range of fuel shares in primary energy consumption compared with 2005 outcome (in \%).

Source: EU Commission $(2011,5)$.

The decarbonization scenarios include: a) High Energy Efficiency scenario that calls for a decrease in energy demand of $41 \%$ by 2050 as compared to the peaks in 2005-2006; b) diversified supply technologies that are driven by carbon pricing assuming public acceptance of both nuclear and Carbon Capture \& Storage (CCS); c) high renewable energy sources (RES) aiming at $75 \%$ in 2050 and a share of RES in electricity consumption reaching 97\%; d) delayed CCS with higher shares for nuclear energy, where decarbonization is driven by carbon prices rather than technology push; and e) low nuclear assuming that no new nuclear reactors are being built resulting in a higher penetration of CCS (32\% in power generation).

The EU Energy Roadmap 2050 argues that "in combination, the scenarios make it possible to extract some conclusions which can help shape decarbonization strategies today which will deliver their full effects by 2020, 2030 and beyond." The EU Energy Roadmap 2050 stated that

The analysis of all scenarios shows that the biggest share of energy supply technologies in 2050 comes from renewables. Thus, the second major prerequisite for a more sustainable and secure energy system is a higher share of renewable energy beyond 2020. In 2030, all the decarbonization scenarios suggest growing shares of renewables of around 30\% in gross final energy consumption.

EU Energy Roadmap 2050 projects that

The share of renewable energy sources (RES) rises substantially in all scenarios, achieving at least 55\% in gross final energy consumption in 2050, up 45 percentage points from today's level at around $10 \%$. The share of RES in 
electricity consumption reaches 64\% in a High Energy Efficiency scenario and $97 \%$ in a High Renewables Scenario that includes significant electricity storage to accommodate varying RES supply even at times of low demand. In moving from 2020 to 2050 the EU Energy Roadmap 2050 suggested a fundamental transformation of the energy system.

It also suggested a "rethinking energy markets" by new ways to manage electricity and integrating local resources and centralized systems, as well as "mobilizing investors" and "engaging the public" and "driving change at the international level" by developing cooperation to build international partnerships on a broader basis. With this Energy Roadmap 2050, the European Commission offered a policy perspective arguing that the goals proclaimed by the heads of states and governments at the G-8 level (2007-2011) are technically feasible but that the transformation would require a strong political will and a sense of urgency among policymakers. To achieve the 20/20/20 EU targets by 2020, Germany, the UK and France adopted ambitious national GHG reduction goals, policies and measures.

In 2008, the German government of Chancellor Merkel adopted eight measures to reduce 2020 levels of GHG emissions by $40 \%$. After the change of the coalition of the CDU with the liberal FDP, this goal was upheld; however, under the assumption that the running time for nuclear reactors would be extended, a goal that was revised in May 2011 in the aftermath of the nuclear catastrophe in Japan. ${ }^{11}$

In the UK, the legally-binding Change Bill of 2007 adopted a target of a $26 \%$ to $32 \%$ reduction in GHG emissions by 2020 and of $60 \%$ reductions by 2050 through these principal measures: a) improving energy efficiency; b) stimulating consumers to become producers at home; and c) investing in the development of low-carbon fuels and technology. ${ }^{12}$

France adopted a strategic energy law of July 13, 2005 (Grenelle 2) that

sets a target of reducing national emissions 3\% per year. [...] The government aims to reduce the energy consumption of public buildings by at least $40 \%$ and to cut their greenhouse gas emissions $50 \%$ by 2020. [...] In the renewables sector, Grenelle 2 sets a goal that 23\% of France's energy use must come from a mix of renewable energy sources by 2020. [...] The law shifts the focus from national energy security [...] to energy efficiency. [...] Grenelle 2 marks a shift away from environmental regulation and toward a broader sustainable development agenda.

11 Bruno De Wachter: "UK and Germany set ambitious emission reduction targets", 20 June 2007; at <http:// www.leonardo-energy.org/uk-and-germany-set-ambitious-emission-reduction-targets $>$; see additional sources at <http://www.euractiv.com/climate-change/germany-plans-cut-climate-emissions-40/article-163424>; Bundesumweltministerium: Klimaagenda 2020: Der Umbau der Industriegesellschaft (Berlin, April 2007); at <http://www.bmu.de/files/pdfs/allgemein/application/pdf/hintergrund_klimaagenda.pdf>.

12 De Wachter, op. cit., 20 June 2007. 
In July 2009, the French Parliament adopted the Grenelle 1 bill. In the National Assembly, "liberals and ecologists voted against the bill [...] because they were concerned about its lack of coherence with more ambitious goals. [...] Despite this resistance, however, the bill passed because the government's party held a majority of seats in the Assembly." ${ }^{3}$

Thus, the three largest EU countries that account for more than $40 \%$ if the EU-27's GHG emissions, in accordance with the strategy of the EU Commission, have not only implemented their GHG reductions goals under the KP and the EU's burden-sharing agreement. They are also committed to GHG reductions by $30 \%$ to $40 \%$ by 2020 . Thus, in the area of international climate policy, the EU has clearly become the leader of a policy strategy that calls for a decarbonization of its economy by 2050 .

\section{Conclusions}

With regard to the reduction targets of the KP, since 1990 the G-8 countries have shown a mixed performance. As a country in transition, Russia had the highest GHG emissions reduction. The EU-27 have clearly met their overall targets under the KP and most member countries have met their national targets under the EU's burden-sharing agreement (1998) based on the KP. Only Canada and the US have clearly failed to stabilize their GHG emissions by the year 2000 to the level of 1990 and to achieve the GHG reduction targets to which they agreed when they signed the KP.

As both the European and North American countries are liberal democracies, the different performance cannot be explained with the system of rule. To explain this fundamentally different performance and especially the fundamental change in public opinion in the US regarding climate change between 2007 and 2012, additional factors must be considered, such as the different political culture in North America and in the EU, the different role of economic interest groups, of powerful lobbies, of the conservative mass media and of a powerful, inward-looking and ideology-driven grassroots movement focusing at the Republican Party that prevented the climate change implementation legislation in US Congress.

The climate paradox hypothesis applies specifically to these two laggards in climate change performance. Canada and the USA share extremely high $\mathrm{CO}_{2}$ emissions per capita and the same "way of life", which is a part of the North American political culture and of the values, attitudes and behavior of most citizens. With the assumption of the world power role during the 1940s, the prevailing thinking on the role of the US in world politics and especially of the

13 Alexander Ochs; Camille Serre, Worldwatch Institute, Washington D.C.: "An Analysis of France's Climate Bill: Green Deal or Great Disillusion?”; at <http://www.worldwatch.org/analysis-france\%E2\%80\%99s-climatebill-green-deal-or-great-disillusion>. 
role of its military tool has significantly changed, as have the dominant theories of international relations from Wilsonian idealism to Hobbesian realism.

The prevailing mindset of business-as-usual and the cornucopian vision that assumes that climate change can be solved with market mechanisms and technical fixes (geo-engineering) are further mental obstacles that restrained the political willingness to launch a new long-term transformation of its economic, cultural, social and political system. Radical climate skeptics portrayed climate change as a major threat to the American way of life and jobs (Klein 2011).

The efforts by ultraconservative climate skeptical movements to attack and delegitimize the IPCC fundamentally contradict the American optimism in scientific progress. Thus, the necessary long-term transformation and the sustainability transition (Grin, Rotmanns and Schot 2010) require in the USA and Canada both a fundamental change of their dominant worldview and consumerist culture, of their values, belief systems, and of the attitudes and behavior of the people and fundamental transformation of the energy system aiming at a progressive decarbonization. This challenges powerful sectors of the economy, the interests of business groups and also of the trade unions representing these old economic sectors.

The proposed new scientific revolution (Clark, Crutzen and Schellnhuber 2012) and the need for a new paradigm shift towards sustainability require to gradually overcome the dominant worldview of the people and the mindset of their political leadership. In international relations, severe crises have often become a driving force for leaning, innovation and change, as the response of Nixon and Kissinger to the Vietnam War indicated, or Gorbachev's efforts to save the socialist model by initiating a new thinking and reforms from the top.

Overcoming the climate paradox in North America requires a deliberate climate leadership of the EU countries and a sustained willingness to unilaterally implement their climate reduction goals and the different roadmaps for 2050. Implementing a sustainability transition with increasing energy efficiency reduces energy costs and enhances the competitiveness of European products. It may also reduce the dependence on fossil imports and thus the involvement in resource conflicts over the control of fossil energy resources.

Overcoming the climate paradox requires a gradual replacement of the thinking and action in terms of business-as-usual towards multiple sustainability transitions in all sectors of the society, of the economy and also in the political realm. To move towards a Fourth Sustainability Revolution (FSR) requires major changes in the dominant culture and way of life, in the dominant societal, economic and political worldview of the citizens and the mindset of their leaders, but also in the forms of governance to curb the influence of political money on the behavior of the elected representatives of the people.

Thus, a dual strategy is needed, a readiness of the people to support such a fundamental change of their culture and way of life, and a willingness of the 
political and economic elites to induce and invest in a long-term transformation of its energy, transportation, housing (heating/cooling), production and consumption systems towards sustainability.

\section{Bibliographic references}

BANURI, Tariq; GÖRAN-MAHLER, Karl; GRUBB, Michael; JACOBSON, Harald \& YAMIN, Ferhana (1996) "Equity and social considerations", in: IPCC (ed.) Climate Change 1995. Impacts, Adaptations and Mitigation of Climate Change. Contributions of Working Group III to the Second Assessment Report of the Intergovernmental Panel on Climate Change, Cambridge University Press, Cambridge, p. 79-124.

BOTZEN, W.J.W.; GOWDY, J.M. \& VAN DEN BERGH, .C.J.M. (2008): "Cumulative $\mathrm{CO}_{2}$ emissions: shifting international responsibilities for climate debt", in: Climate Policy, 8, p. 569-576.

BRAUCH, Hans Günter (2009) "Securitizing Global Environmental Change", in: Brauch et al. (Eds.), 2009: Facing Global Environmental Change: Environmental, Human, Energy, Food, Health and Water Security Concepts, Springer-Verlag, Berlin - Heidelberg - New York, p. 65-102.

CANADA, 2010: Fifth National Communication of Canada: Actions to Meet Commitments under the UNFCCC (Ottawa: Government of Canada).

CAR [U.S. Climate Action Report] 2010: Fifth National Communication of the United States of America Under the UNFCCC (Washington, D.F.: Global Publishing Service)

CLARK, William C.; CRUTZEN, Paul J. \& SCHELLNHUBER, Hans Joachim (2004) "Science and Global Sustainability: Toward a New Paradigm", in: Schellnhuber, Hans Joachim et al. Earth System Analysis for Sustainability, MIT Press, Cambridge, MA, p. 1-28.

DESAI, Surajee; MICHAELOWA, A. (2001) "Burden sharing and cohesion countries in European climate policy: a case study from Portugal”, in: Climate Policy, Vol. 1, No. 3, p. $327-341$.

EU [European Commission, Council] (2008) Climate Change and International Security. Paper from the High Representative and the European Commission to the European Council, S113/08, Brussels, 14 March 2008.

GRIN, John; ROTMANNS, Jan \& SCHOT, Johan, 2010: Transitions to Sustainable Development. New Directions in the Study of Long Term Transformative Change (New York, NY - London: Routledge).

OHTA, Hiroshi (2011) "Japanese Climate Change Policy: Moving Beyond the Kyoto Process", in: BRAUCH, Hans Günter et al.: Coping with Global Environmental Change, Disasters and Security - Threats, Challenges, Vulnerabilities and Risks, Springer-Verlag, Berlin - Heidelberg New York, p. 1381-1392.

HÖHNE, N. et al. (September 24, 2010): "Contributions of individual countries' emissions to climate change and their uncertainty", in: Climatic Change (Springer).

IEA (2011) IEA Statistics, 2011 Edition: $\mathrm{CO}_{2}$ Emissions From Fuel combustion Highlights, OECD/IEA, Paris.

KLEIN, Naomi (2011) "Capitalism vs. the Climate", in: The Nation, 28 November 2011. 
KRUPP, Helmar (1997) “Japanische Energiepolitik”, in: Brauch, Hans Günter (Ed.): Energiepolitik - Technische Entwicklung, politische Strategien, Handlungskonzepte zu erneuerbaren Energien und zur rationellen Energienutzung, Springer, Berlin - Heidelberg, p. 243-252.

OSWALD SPRING, Úrsula \& BRAUCH, Hans Günter (2011) “Coping with Global Environmental Change - Sustainability Revolution and Sustainable Peace”, in: BRAUCH, Hans Günter et al.: Coping with Global Environmental Change, Disasters and Security - Threats, Challenges, Vulnerabilities and Risks, Springer-Verlag, Berlin - Heidelberg - New York, p. 1487-1504.

SCHEFFRAN, Jürgen; BRZOSKA, Michael; BRAUCH, Hans Günter et al. (eds): Climate Change, Human Security and Violent Conflict: Challenges for Societal Stability, Springer-Verlag, Berlin - Heidelberg.

UNDP (2011) Human Development Report 2011: Sustainability and Equity: A Better Future for All, UNDP, New York.

UN-SG (2009) Climate change and its possible security implications. Report of the SecretaryGeneral. A/64/350 of 11 September 2009, United Nations, New York.

Received August 17, 2012 Accepted September 15, 2012

\section{Abstract}

This article analyzes the climate policy performance of the G-8 from 1992 to 2012 based on their legal commitments (Annex-1 and Annex-B countries) under the UNFCCC (1992) and the Kyoto Protocol (1997) and their policy declarations on their GHG reduction goals until 2050. A climate paradox has emerged due to a growing implementation gap in Canada, USA and Japan, while Russia, Germany, UK, France and Italy fulfilled their GHG reduction obligation.

Keywords: climate paradox; G-8; policy implementation gap.

\section{Resumo}

Este artigo analisa o desempenho da política climática do G-8, desde 1992 até 2012, com base em seus compromissos legais (países do Anexo 1 e Anexo B) sob o UNFCCC (1992) e sob o Protocolo de Quioto (1997) e suas declarações políticas sobre suas metas para a redução de gases do efeito estufa (GHG) até 2050. Emergiu um paradoxo climático, devido à crescente lacuna de implementação dessas políticas no Canadá, nos Estados Unidos e no Japão, enquanto a Rússia, o Reino Unido, a França e a Itália cumpriram suas obrigações de redução de GHG.

Palavras-chave: paradoxo climático; G-8; lacuna de implementação de políticas. 